Дьяченко Юлія Володимирівна кандидат економічних наук, доцент кафедри менеджменту і логістики Одеської національної академії харчових технологій, вул. Канатна, 112, м. Одеса, 650 39, тел.: (0 48) 712-40-38, e-mail: ypogarchuk@gmail.com, https://orcid.org/0000-0002-8754-3256

Бондар Вікторія Анатоліївна кандидат економічних наук, старший викладач кафедри менеджменту і логістики Одеської національної академії харчових технологій, вул. Канатна, 112, м. Одеса, 65039, тел.: (048) 712-40-38, e-mail: bondarv1801@ gmail.com, https://orcid.org/0000-0002-0419-6579

\title{
ЗНАЧЕННЯ ІВЕНТ-МЕНЕДЖМЕНТУ У ФОРМУВАННІ ТУРИСТИЧНОЇ ПРИВАБЛИВОСТІ ТЕРИТОРІЇ
}

Анотація. В статті розглянуті такі поняття як «івент-захід», «івентдіяльність», «івент-менеджмент». Івент-захід - це унікальна подія, що створюється в процесі івент-діяльності, яка, в свою чергу, вимагає специфічного менеджменту. Івент-менеджмент представляє собою процес розробки, управління і контролю за проектом, що здійснюється підготовленими фахівцями. Сьогодні в Україні простежується тенденція до активізації професіоналізації івент-діяльності i процесу формування івент-менеджерів як особливої професійної групи. Професіоналізація івент-діяльності включає в себе три етапи: 1) пізнавальну інституціоналізацію, 2) організаційну інституціоналізацію і професійну інституціоналізацію. На нашу думку, вітчизняна івент індустрія знаходиться на другому етапі - це етап формування правил, норм професійної діяльності, вимог до фахівців і їх поширення івент-асоціаціями на «професіоналів», об'єднання в професійні спілки.

В дослідженні проаналізовано специфіку івент-менеджменту і поширеність деяких типів івент-заходів в діяльності органів влади і компаніях різних секторів економіки (фінансові організації; IT-компанії; ритейлери; медичні компанії; промисловці; телеком-оператори; підприємства сфери послуг для бізнесу).

Івент-менеджмент в діяльності органів державного управління та місцевого самоврядування використовують також 3 метою формування туристичної привабливості території. Проведення комплексу яскравих івент-заходів, спрямованих на просування території, популяризує іiі, впливає на свідомість цільової аудиторії, дозволяє наблизити територіальний продукт до споживача, 
встановити емоційний зв'язок між ними, створює атмосферу, що відповідає концепції бренду території. Івент-менеджмент застосовується i в подієвому туризмі, а також передбачає використання інструментів подієвого маркетингу, що дозволяє не тільки залучати туристичні потоки, але також збільшити термін їх перебування в дестинації, яка є майданчиком для проведення заходів.

Ключові слова: івент-менеджмент, подієвий туризм, туристична привабливість території, дестинація, публічне управління.

DiachenkoYuliia Volodymyrivna $\mathrm{PhD}$ in Economics, Associate Professor of the Department of Management and Logistics, Odessa National Academy of Food Technologies, Kanatna st., 112, Odessa, 65039, tel.: (048) 712-40-38, email: ypogarchuk@gmail.com, https://orcid.org/0000-0002-8754-3256

Bondar Viktoriia Anatoliivna PhD in Economics, Assistant of the Department of Management and Logistics, Odessa National Academy of Food Technologies, Kanatna st., 112, Odessa, 65039, tel.: (048) 712-40-38, e-mail: bondarv1801@gmail.com, https://orcid.org/0000-0002-0419-6579

\section{THE IMPORTANCE OF THE EVENT MANAGEMENT IN FORMING THE TERRITORY'S TOURIST ATTRACTION}

Abstract. The article discussed such concepts as "event", "event-activity", "event management". An event-action - is a unique event that is created in the process of event-activity, which, in turn, requires specific management. Event management is a process of development, management and control of a project, carried out by trained specialists. Today in Ukraine there is a tendency to intensify the professionalization of event-activity and the process of forming event-managers as a special professional group. Professionalization of event-activity includes three stages: 1) cognitive institutionalization, 2) organizational institutionalization and professional institutionalization. In our opinion, the domestic event industry is at the second stage this is the stage of the formation of rules, norms of the professional activity, requirements for specialists and their distribution by event-associations to "professionals", and the integration into the trade unions.

In the study analyzed the specificity of event management and the prevalence of certain types of events in the activities of government authorities and companies in various sectors of the economy (financial organizations; IT-companies; retailers, medical companies; industrialists; telecom-operators, service providers for business).

Event management in the activities of state and local government bodies is also used to form the tourist attractiveness of the territory. Holding a complex of bright 
events aimed at promoting the territory, popularizing it, influencing the consciousness of the target audience, bringing the territorial product closer to the consumer, establishing an emotional connection between them, creating an atmosphere corresponding to the concept of the territory brand. Event management is also used in event tourism, and also provides for the use of event marketing tools, allows not only to attract tourist flows, but also to increase their stay in the destination, which is a venue for events.

Keywords: event management, event tourism, tourist attractiveness of the territory, destination, public administration.

Постановка проблеми. Використання івент-менеджменту в контексті формування туристичної привабливості території набуває сьогодні особливої актуальності, адже інформаційне середовище $є$ високо насиченим і виникає потреба в пошуку нових інструментів просування туристичних дестинацій. Саме організація івентів, як унікальних, неповторних подій, що здатні залучити туристів до певної території, створити емоційний зв'язок 3 дестинацією, сформувати бренд території потребує особливої уваги на наш погляд і обумовлює вибір теми даного дослідження.

Аналіз останніх досліджень і публікацій. Дослідженням питань, пов'язаних iз розвитком івент-менеджменту, займалися зарубіжні та вітчизняні науковці, такі як У. Хальцбаур, Е. Йеттінгер, Б. Кнаус, Р. Мозер, М. Целлер [1], Дж. Голдблатт [2], О. Шумович [3]. Використання івентів в просуванні територій досліджується в роботах Климової Т.Б., Вишневської О.В., Аноприєвої О.В. [4], Писаревої І. В., Радіонової О. М., Приходько, М. Д. [5] та ін.

Мета статті полягає у дослідженні розвитку івент-менеджменту в Україні та 3’ясуванні його ролі у формуванні туристичної привабливості території.

Виклад основного матеріалу. Термін «івент» можна визначити як професійно спланований i організований захід в різноманітних сферах суспільного життя, який призначений для певного кола людей i $є$ для них значущим і унікальним, обмежений в часі і просторі і спрямований на вирішення конкретних цілей і завдань, що забезпечується використанням різних ресурсів.

Івент-захід як унікальна подія створюється в процесі івент-діяльності, яка, в свою чергу, передбачає розмежування процесів управління заходом i його безпосередньої реалізації. Процес управління заходом представляє собою івентменеджмент, змістом якого є івент-проект - він розробляється, управляється і контролюється івент-менеджерами та реалізується виконавцями.

Івент-діяльність вимагає специфічного менеджменту, для здійснення якого необхідні підготовлені фахівці івент-менеджери - це суб'єкти управління, які виконують ряд функцій з проектування та управління івент-проектом, а саме 
розробляють івент-проекти, організовують власну діяльність і діяльність підпорядкованих їм суб'єктів щодо реалізації івент-проекту.

Виходячи 3 аналізу підходів до сутності професій i професійних груп, сьогодні $\epsilon$ необхідність розгляду івент-діяльності та івент-менеджерів як нових професійних феноменів, що знаходяться на стадії формування та володіють відповідними ознаками. До таких характерних ознак можна віднести закріплення діяльності за особливою групою, формування специфічного знання і автономії, існування особливих символів, атрибутів професії. Цей список продовжують риси, що формують певну професійну групу івент-менеджерів, а саме: реалізація ними особливих функцій, наявність професійних знань і умінь, що здобуті в рамках системи освіти і в процесі професійного досвіду, наявність професійної ідентичності, орієнтація на професійну автономію.

В рамках дослідження встановлено, що група івент-менеджерів складається 3 івенторів-«професіоналів» і «непрофесіоналів». «Професіонали» - це івентменеджери, які виконують управлінські функції в процесі підготовки і реалізаціі івент-проекту; володіють професійними знаннями, які були отримані в рамках системи івент-освіти, а також мають досвід роботи на посаді івент-менеджера; ідентифікують себе 3 професійною групою івент-менеджерів; мають інтерес, потребу, готовність до активізації професіоналізації івент-діяльності і процесу формування івент-менеджерів як особливої професійної групи. «Професіоналам» властиві професійні якості, засновані на знаннях і уміннях в сфері менеджменту i маркетингу, а також в сфері художньо-творчої діяльності. «Непрофесіонали» - це виконавці, які беруть на себе управлінські функції, але не можуть забезпечити якісне їх виконання; фахівці, які тільки частково володіють характеристиками, що властиві івент-менеджерам, а саме, самоідентифікуються з групою івенторів, що дозволяє їм видавати себе за «професіоналів» [6].

Івент-менеджерів-«професіоналів» і «непрофесіоналів» характеризують різні професійні та особистісні якості. На відміну від «професіоналів» «непрофесіонали» не володіють основними управлінськими компетенціями, вони не можуть якісно спланувати івент-проект, забезпечити управління ним і провести контроль і оцінку його ефективності. Вони не володіють важливими для івентменеджера особистісними якостями, такими як відповідальність, стресостійкість, реактивність, орієнтація на професійний розвиток, уміння вибудовувати продуктивну комунікацію $з$ клієнтами, партнерами на всіх етапах підготовки i реалізації івент-проекту.

Івент-менеджери «професіонали» використовують стратегіï, що засновані на ефективному застосуванні культурного, соціального, економічного і владного капіталу, для утримання своїх позицій в івент-полі, проте в силу відсутності у них 
легітимного статусу і діючих механізмів впливу на «непрофесіоналів» їх поки не можна назвати «домінуючими» агентами в івент-полі, що формується.

Простежується тенденція до професіоналізації івент-діяльності та зайняття івенторами-«професіоналами» кращих позицій, адже «непрофесіонали» не орієнтовані на приріст свого культурного і владного капіталу, а збільшення економічного капіталу вони досягають екстенсивним шляхом (беруть велику кількість замовлень, демпінгують ціни на івент-послуги), і це свідчить про те, що з часом вони можуть втратити свої позиції в івент-полі. Однак соціальний капітал (професійні зв'язки і неформальні угоди), що мають івентори-«непрофесіонали» досить стійкий і забезпечує їм поточну позицію в івент-полі [6].

Під професіоналізацією івент-діяльності ми розуміємо поступовий процес послідовного формування інституційних ознак професії івент-менеджера, тобто процес становлення правил, норм, що регулюють поведінку івент-менеджерів, а також установ, які забезпечують управління і здійснення контролю за дотриманням цих правил і норм.

Професіоналізація івент-діяльності включає в себе три етапи, зміст яких визначає структуру процесу формування івент-менеджерів як професійної групи:

1) Пізнавальна інституціоналізація - етап затвердження теоретичних основ (знань, навичок), що є необхідними для здійснення професійної діяльності івентменеджера, i трансляція їх на всю професійну групу за допомогою освітніх установ. На цьому етапі івентори, які набувають професійні знання, вміння, мають можливість перейти зі статусу «непрофесіоналів» в статус «професіоналів».

2) Організаційна інституціоналізація - етап формування правил, норм професійної діяльності, вимог до івенторів і їх поширення на «професіоналів» івент-асоціаціями. На даному етапі івентори-«професіонали» відчувають потребу в об'єднанні, в відокремленні від «непрофесіоналів» i задовольняють iі, вступаючи в професійні спілки.

3) Професійна інституціоналізація - етап легітимації івент-діяльності i визначення івент-менеджерів як професійної групи на державному рівні. Цей етап повинен завершити професійне становлення івенторов-«професіоналів», витіснити «непрофесіоналів» на периферію івент-поля - в сферу виконавчої діяльності.

Сьогодні процес професіоналізації івент-діяльності і формування івентменеджерів як професійної групи в Україні ще не завершено і знаходиться на другому етапі. Івент-менеджери остаточно сформують особливу професійну групу при деяких умовах: якщо івентори через івент-асоціації будуть активно відстоювати право групи на професійне визначення і держава буде реагувати на подібні ініціативи. 
Івент-діяльність має свої особливості, адже в кожній галузі є певна специфіка і поширеність деяких типів івент-заходів - тих, які найбільше відповідають певній цільової аудиторії. Навіть івенти одного типу можуть помітно відрізнятися, залежно від того, до якої галузі відноситься компанія-організатор - це підтверджує дослідження The Harvard Business Review [7]. Дослідники опитали більше 700 міжнародних компаній про те, заходи якого типу вони проводили або спонсорували останнім часом. До складу респондентів увійшли: фінансові організації; ІТ-компанії; ритейлери; медичні компанії; промисловці; телекомоператори; підприємства сфери послуг для бізнесу. Результати цього опитування представлені на рис. 1.

\begin{tabular}{|c|c|}
\hline \% опитаних. які & • організовували такий захід \\
\hline Одноденні конференції та семінари & 435 \\
\hline тренінги по продукту & $\pi \%$ \\
\hline Дилерські в'ізди, конференції для партнерів & $41 \mathrm{~K}$ \\
\hline Практичні семінари, воркшопи & $26 \mathrm{x}$ \\
\hline VIP-сніданки / обіди / вечері & $25 x$ \\
\hline Презентація продукту & 165 \\
\hline Багатоденні конференціі & $40 \mathrm{x}$ \\
\hline Заходи для преси та блогерів & 235 \\
\hline Пересувні експозиціі & $16 \mathrm{x}$ \\
\hline Галузеві виставки та конгреси & 548 \\
\hline Церемонії нагородження & 328 \\
\hline Зустрічі користувачів продукту & $28 \mathrm{~s}$ \\
\hline Вечірки & $17 \mathrm{x}$ \\
\hline Лекції & 228 \\
\hline Мітапи, зустрічі професійної спільноти & 95 \\
\hline $\begin{array}{l}\text { Семінари або майстер-класи на галузевих } \\
\text { конференціях }\end{array}$ & $25 \mathrm{~K}$ \\
\hline Благодійні та фандрайзингової івенти & 245 \\
\hline Виізні наради і семінари & 245 \\
\hline Розважальні заходи & 235 \\
\hline Інсентив-тури & 205 \\
\hline Акції в торговельних точках & Bex \\
\hline дегустаціі & 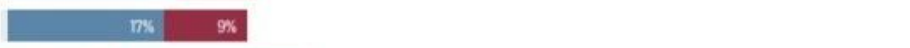 \\
\hline Культурні фестивалі & $2 \mathrm{~K}$ \\
\hline Оренда площі для виставки товару & $105 \quad 7 \%$ \\
\hline Музичні фестивалі & $15 x$ \\
\hline жоден & $14 \times$ \\
\hline
\end{tabular}

Рис. 1. Найбільи поширені типи івент-заходів [7]

Фінансові організації (банки, інвестиційні, страхові, лізингові компанії і т.д.) основний акцент роблять на освітніх івент-заходах. Фінансові послуги - це складний продукт, який не можна «взяти на тест-драйв». До того ж, важливою складовою успіху на ринку для таких компаній є високий рівень довіри і визнання їх експертності. Згідно з дослідженням, найчастіше вони проводять одноденні семінари або воркшопи. Наочно показати i навчити - ефективний спосіб просувати складні послуги i одночасно формувати репутацію експерта у фінансовій галузі. 3 іншого боку, більшу частину бюджету на спонсорство ці 
компанії витрачають на розважальні заходи та благодійні івенти, не оминаючи увагою і галузеві конгреси.

Найбільше освітніх івент-заходів проводять технологічні компанії, що займаються розробкою програмного забезпечення, консультуванням у сфері IT та інтернет-послугами. В арсеналі ІT-компанії провідне місце займають одноденні конференції, заходи для дилерів і партнерів, а також воркшопи та тренінги по продукту. Складні продукти вимагають навчання, до того ж на таких заходах існуючі та майбутні користувачі спілкуються, обмінюються досвідом та формують лояльну до бренду спільноту. Крім того, популярністю в технологічних компаніях користуються VIP-сніданки, обіди та вечері, на яких є можливість поспілкуватися 3 найбільшими замовниками в неформальній обстановці. Що стосується спонсорованих заходів, 3 великим відривом лідирують галузеві виставки та конгреси. Компаніям, які працюють переважно в В2В-сегменті, галузеві виставки допомагають познайомити 3 продуктом максимально велике число споживачів і професіоналів індустрії.

Ритейлери у своїй статегї роблять акцент на активностях безпосередньо в торгових точках з метою залучення якнайбільшої кількості покупців у торговельні точки. 3 метою підвищення впізнаваності бренду ритейлери також надають спонсорську підтримку різним заходам, найбільш популярні 3 яких масові розважальні заходи, а також заходи для преси і блогерів.

Сектор охорони здоров'я представлений широким спектром - це і лікарні, $\mathrm{i}$ медичні страхові компанії, і безпосередньо виробництво лікарських засобів. Для компаній даної галузі івент-заходами, що найчастіше влаштовуються, є лекції та конференції для лікарів. Це цілком очікувано, адже індустрія охорони здоров'я знаходиться в постійному розвитку і компанії організовують освітні заходи, щоб поділитися новітніми досягненнями та ідеями або результатами медичних досліджень. Компанії в секторі охорони здоров'я також активно спонсорують заходи цього типу, виступаючи партнерами на великих медичних конференціях i конгресах, однак найбільш популярними для спонсорства є благодійні івентзаходи.

Виробничий сектор включає в себе компанії, які так чи інакше залучені в процес переробки i виробництва товарів повсякденного попиту: текстилю, автомобілів, продуктів харчування. Компанії-виробники найбільше коштів вкладають в організацію івент-заходів, які пов'язані із просуванням конкретних продуктів, але орієнтуються не на кінцевих споживачів, а на партнерів (дилерів, ритейлерів). В першу чергу, це тренінги по продуктах і презентації новинок. Також популярними заходами є одноденні конференції по продукції. Акцент на заходах, пов'язаних із продуктами, зберігається і при виборі спонсорованих івентів. Тому найбільш популярним типом таких івентів є галузеві виставки, які 
дозволяють продемонструвати свою продукцію новим потенційним партнерам.

Під телеком-компаніями маються на увазі мобільні оператори, оператори платного ТБ і інтернет-провайдери. Ці компанії обирають івент-заходи, що спрямовані на стимулювання попиту і популяризацію послуг для споживачів. Презентація новинок, одноденні освітні семінари і пересувні експозиції допомагають донести інформацію про нові продукти потенційним клієнтам. Для спонсорування обирають такі заходи як: галузеві виставки / конгреси, багатоденні конференції та розважальні івенти.

Сектор професійних і ділових послуг включає в себе компанії, які надають послуги іншим організаціям (реклама i PR, консалтинг, навчання персоналу), a також представникам певних професій. Найбільш популярними типами івентзаходів, що проводяться в цій галузі, є конференції, воркшопи та VIP-сніданки / обіди / вечері. Для таких компаній важливу роль відіграють також великі освітні заходи, оскільки вони дозволяють встановити зв'язок з великою клієнтською базою. Що стосується спонсорської діяльності, компанії цього сектора вважають за краще спонсорувати івент-заходи, на яких вони можуть продемонструвати свій бренд якомога більшій кількості людей: галузеві виставки та конгреси, а також одноденні конференції та семінари.

Також організація і проведення заходів є невід'ємною частиною діяльності органів державного управління та місцевого самоврядування. Івент-діяльність в сфері публічного управління та адміністрування полягає в управлінні підготовкою різноманітних типів заходів, а саме: церемоній, святкування пам'ятних дат, нагородження, спортивних змагань, фестивалів, виставок, ярмарків, презентацій, масових свят, концертів, благодійних акцій і аукціонів, зборів, з’їдів, конгресів, самітів, круглих столів, сесій, прес-конференцій тощо. В даному випадку івентзахід виступає ще як канал комунікацій, адже будь-якому комунікативному процесу притаманні такі складові: суб’єкт-комунікатор - в цій ролі виступають органи державного управління різних гілок влади, які передають інформацію; об'єкт-рецепієнт (одержувач) - це суспільство, громади; засоби масової інформації - виступають каналом зв’язку i активним учасником процесу реформування.

Система маркетингових комунікацій, що використовуються в діяльності сучасних органів публічного управління, представлена засобами, які умовно поділяють на дві групи: основні і синтетичні. До основних можна віднести зв'язки 3 громадськістю, прямий маркетинг, рекламу, стимулювання збуту - вони присутні в структурі інших специфічних комунікаційних засобів: брендинг, інтегровані маркетингові комунікації на місці надання управлінських та адміністративних послуг, ярмаркова, виставкова діяльність тощо. Синтетичний засіб маркетингових комунікацій - івент-менеджмент, отримує все більше 
поширення в діяльності органів влади. Особливої актуальності івент-менеджмент набуває в контексті формування туристичної привабливості території, адже в сучасних умовах високої насиченості інформаційного середовища, виникає необхідність в застосуванні нових підходів до організації просування, в тому числі і туристичних дестинацій.

В цьому контексті івент-менеджмент можна розглядати як комплекс заходів, спрямованих на просування території, iї популяризацію за допомогою яскравих подій, спеціальних заходів. Спеціальні заходи, впливаючи на свідомість цільової аудиторії, дозволяють наблизити територіальний продукт до споживача, зміцнити емоційний зв'язок конкретного місця і споживача, створити атмосферу, що буде ідеально відповідати бренду території.

Концепція івент-менеджменту застосовується в подієвому туризмі, а також передбачає використання інструментів подієвого маркетингу, що дозволяє не тільки залучати туристичні потоки, але також збільшити термін їх перебування в дестинації, яка є майданчиком для проведення заходів. При цьому слід розрізняти подієвий маркетинг і подієвий туризм. Подієвий туризм - вид туризму, при якому туристичні поїздки приурочені до певних подій або заходів, акцент робиться саме на організацію заходів, а подієвий маркетинг передбачає практику просування інтересів території за допомогою різних значущих подій, тут основою $\epsilon$ територіальний продукт і виходячи з його характеристик організовуються події, проведення яких дозволить створити, підтримати або розвинути турпотоки, сформувати туристичну привабливість території.

У подієвому туризмі ключовий об'єкт - це захід або подія, до якого приурочені поїздки і цей захід може проводитися на різних територіях, а для просування цих заходів застосовується подієвий маркетинг. У подієвому маркетингу туристичних дестинацій об'єктом $є$ територіальний продукт, а подія стає інструментом просування цього продукту [4].

За допомогою івент-заходу як інструменту просування території досягається кілька ефектів:

1) інтерес потенційних споживачів туристичних послуг, які знаходяться на стадії прийняття рішень;

2) популярний івет-захід сам стає брендом, що дозволяє широко використовувати його при побудові стратегії просування території;

3) створення інфо-приводу для ЗМІ, що створює довгостроковий ефект;

4) учасники заходу можуть розглядатися як велика фокусгруппа, що дозволяє накопичувати знання про споживача події послуги;

5) вплив на емоційну складову цільової аудиторії, що дозволяє території на довгий період залишатися в пам'яті;

6) ненав'язливість інформації при увазі широкої громадськості; 
7) ефект сарафанного радіо;

8) каталізація розвитку суміжних галузей і напрямків діяльності (туризм, міський менеджмент, державно-приватне партнерство);

9) зниження сезонних коливань на туристичні продукти [5].

Незалежно від характеру івент-заходу: чи то інформаційно-пізнавальні або спортивно-розважальні події, головне, щоб вони відповідали бренду туристичного продукту. Відсутність гармонії може привести до ослаблення і підриву сформованого образу дестинації. Наскільки ефективно буде застосування інструментів подієвого маркетингу, залежить від правильного виділення цільової аудиторії, вибору каналів комунікацій, часу проведення заходу, організації та злагодженої роботи по його проведенню усіх зацікавлених сторін. Синергетичного ефекту можна досягти при проведенні комплексу взаємопов'язаних заходів (особливо в довгостроковій перспективі) або при застосуванні подієвого маркетингу у взаємозв'язку 3 іншими елементами комплексу маркетингу.

Слід зазначити, що організація та проведення івент-заходів дозволяє активізувати зацікавленість туристів у відвідуванні визначених територій, але рівень споживчої задоволеності і лояльності до туристичної дестинації формує не тільки сам захід, який привернув увагу туриста, а й те, як цей захід вписано в інші пропозиції туристичної дестинації. Тобто важливим $є$ розвиток туристичної інфраструктури: стан навколишнього середовища, політична стабільність, рівень розвитку транспортної інфраструктури, місць розміщення, харчування і т. п. Отже, привабливість івент-заходу повинна бути підкріплена туристичною привабливістю - тоді це слугуватиме каталізатором процесу популяризації туристичної дестинації.

Висновки. В результаті проведеного дослідження нами було: - розкрито сутність понять «івент-захід», «івент-діяльність», «івент-менеджмент»; встановлено, що на сьогодні простежується тенденція до професіоналізації івентдіяльності в Україні; - проаналізовано специфіку івент-менеджменту в компаніях різних секторів економіки та в діяльності органів влади; - доведено, що ефективність заходів, які організують органи державного управління та місцевого самоврядування може бути суттєво підвищена за умови використання на практиці інструментів івент-менеджменту; - визначено місце і значення івент-менеджменту у формуванні туристичної привабливості території.

\section{Лimepamypa:}

1. Хальцбаур У., Йеттингер Э., Кнаусе Б., Мозер Р., Целлер М. Event-менеджмент / Пер. с нем. Т. Фоминой. Москва, 2007. 384 с.

2. Goldblatt J. Special Events: A new generation and the next frontier: ed. a 6-th, Hoboken: John Wiley \& Sons, Inc., Ltd, 2011. 592 p. 
3. Шумович А.В. Великолепные мероприятия. Технологии и практика eventmanagement. Москва, 2009. 336 с.

4. Климова Т.Б., Вишневская Е.В., Аноприева Е.В. Продвижение территории посредством взаимодействия событийного маркетинга и событийного туризма. Вісник Харківського національного університету імені В.Н. Каразіна. Серія: «Міжнародні відносини. Економіка. Країнознавство. Туризм». 2013. №1086. Вип. 2. С. 147-150.

5. Писарева I. В., Радіонова О. М., Приходько М. Д. Розвиток подієвого туризму та його вплив на просування території. Економічний простір. 2020. №161. С. 104-109.

6. Старцева Н.Н. Ивент-менеджеры профессионалы и непрофессионалы: характеристика агентов поля ивент-деятельности. Современные исследования социальных проблем. 2015. №1 (45). С.308-321.

7. The Event Marketing Evolution: An Era of Data, Technology and Revenue Impact. URL: https://3rxg9qea18zhtl6s2u8jammft-wpengine.netdna-ssl.com/wp-

content/uploads/2018/09/20982_HBR_ResearchReport_Splash_11.pdf (дата звернення 18.02.2020).

\section{References:}

1. Khaltsbaur U., Yettinger E., Knause B., Mozer R., Tseller M. (2007). Event-menedzhment [Event management] / Per. s nem. T. Fominoy. Moskva [in Russian]

2. Goldblatt J. (2011). Special Events: A new generation and the next frontier: ed. a 6-th, Hoboken: John Wiley \& Sons, Inc., Ltd [in English]

3. Shumovich A.V. (2009). Velikolepnye meropriyatiya. Tekhnologii i praktika eventmanagement. [Great events. Event management technologies and practice]. Moskva [in Russian]

4. Klimova T.B., Vishnevskaya Ye.V., Anoprieva Ye.V. (2013). Prodvizhenie territorii posredstvom vzaimodeystviya sobytiynogo marketinga i sobytiynogo turizma [Promotion of the territory through the interaction of event marketing and event tourism]. Visnyk Kharkivskoho natsionalnoho universytetu imeni V.N. Karazina. Seriia: «Mizhnarodni vidnosyny. Ekonomika. Krainoznavstvo. Turyzm» - Bulletin of Kharkiv V.N. Karazina National University. Series: «International Relations. Economy. Local lore. Tourism», 1086 (2), 147-150 [in Russian]

5. Pysareva I. V., Radionova O. M., Prykhodko M. D. (2020). Rozvytok podiievoho turyzmu ta yoho vplyv na prosuvannia terytorii [Development of event tourism and its impact on the promotion of the territory]. Ekonomichnyi prostir - Economic space, 161, 104-109 [in Ukrainian]

6. Startseva N.N. (2015). Ivent-menedzhery professionaly i neprofessionaly: kharakteristika agentov polya ivent-deyatelnosti [Event managers professionals and non-professionals: characteristics the agents of the event activity field]. Sovremennye issledovaniya sotsialnykh problem - Modern research of social problems, 1 (45), 308-321 [in Russian]

7. The Event Marketing Evolution: An Era of Data, Technology and Revenue Impact. URL: https://3rxg9qea18zhtl6s2u8jammft-wpengine.netdna-ssl.com/wpcontent/uploads/2018/09/20982_HBR_ResearchReport_Splash_11.pdf [in English] 